\title{
CORRECTIVE JUSTICE AND REDRESS UNDER AUSTRALIA'S RACIAL VILIFICATION LAWS
}

\begin{abstract}
BiLl SWANNIE*
This article examines the process for seeking redress under Australia's racial vilification laws. Recently, the debate concerning pt IIA of the Racial Discrimination Act 1975 (Cth) has focused on unmeritorious complaints and the importance of quickly terminating such complaints. This article argues that pt IIA establishes a civil wrong and that corrective justice provides an appropriate framework for understanding the process by which complainants may seek redress for this wrong. However, the remedial process currently fails to provide corrective justice in two ways. First, conciliation is compulsory and this unduly restricts complainants from commencing proceedings. This is inconsistent with the public character of vilification, which indicates that public vindication may be more appropriate than private settlement. Second, current costs rules may deter complainants from seeking vindication of their rights. Therefore, these rules should be modified in proceedings for racial vilification.
\end{abstract}

\section{INTRODUCTION}

The debate concerning Australia's racial vilification laws has recently moved from focusing primarily on the substantive provisions, contained in pt IIA of the Racial Discrimination Act 1975 (Cth) ('RDA'), ${ }^{1}$ to issues concerning procedure, enforcement and redress. In 2017, Parliament amended the relevant procedural provisions, contained in the Australian Human Rights Commission Act 1986 (Cth) ('AHRCA'), ${ }^{2}$ following an inquiry and report that highlighted the cost of unmeritorious complaints, and the need to prevent such complaints from

\footnotetext{
Lecturer, College of Law and Justice, Victoria University; PhD candidate, Monash University. Email: Bill.Swannie@vu.edu.au; ORCID iD: 0000-0002-5540-8105. The author thanks Associate Professor Patrick Emerton and Dr Colin Campbell, and the reviewers and editors, for their assistance with this article.

This article focuses on pt IIA of the Racial Discrimination Act 1975 (Cth) ('RDA'), which was inserted into the RDA by the Racial Hatred Act 1995 (Cth). Most Australian states and territories have similar laws. However, the RDA is the only national law concerning racial vilification.

Human Rights Legislation Amendment Act 2017 (Cth), which commenced on 13 April 2017. Part IIA and $\mathrm{B}$ of this article examine this amendment.
} 
proceeding to court. ${ }^{3}$ On the other hand, scholars such as Gelber and McNamara highlight the risks and burdens faced by people who seek to enforce their rights under pt IIA.4 Further, they argue that, due to the 'public' nature of the wrong of racial vilification, the state should have a larger role in enforcing these laws. ${ }^{5}$

This article argues that corrective justice provides an appropriate framework for understanding, and evaluating proposed changes to, the process by which victims of racial vilification may seek redress for that wrong. Corrective justice applies generally to civil wrongs involving the infringement of individual legal rights. It requires the state to provide appropriate mechanisms for individuals to seek redress in respect of such wrongs. Further, this article argues that appropriate and adequate redress for racial vilification is not currently provided under Australian law, and suggests two legislative amendments to remedy this situation.

Part II of the article argues that the remedial process set out in the AHRCA should be understood within a corrective justice framework. When pt IIA of the $R D A$ was enacted, its protective and remedial purpose was emphasised both in the legislative text and in parliamentary statements. ${ }^{6}$ Further, pt IIA imposes civil liability on respondents in respect of racial vilification (as defined by s 18C), and a person 'aggrieved' by such conduct may make a complaint and pursue legal redress in respect of that conduct.7 Breach of pt IIA therefore creates correlative

Commonwealth of Australia, Parliamentary Joint Committee on Human Rights, Freedom of Speech in Australia: Inquiry into the Operation of Part IIA of the Racial Discrimination Act 1975 (Cth) and Related Procedures under the Australian Human Rights Commission Act 1986 (Cth) (Inquiry Report, February 2017) ('Freedom of Speech Report').

$4 \quad$ Katharine Gelber and Luke McNamara, 'Private Litigation to Address a Public Wrong: A Study of Australia's Regulatory Response to "Hate Speech"' (2014) 33(3) Civil Justice Quarterly 306. This article uses the terms 'complainant', 'applicant' and 'claimant' as references to persons who make a claim under pt IIA of the RDA. The Australian Human Rights Commission Act 1986 (Cth) ('AHRCA') uses the terms 'complainant' and 'applicant', in relation to the two stages for seeking redress (see Part IIA of this article). The term 'claimant' is generally used in the literature examined in this article. These terms are largely synonymous for the purposes of this article.

5 Ibid. See also Katharine Gelber and Luke McNamara, 'Anti-Vilification Laws and Public Racism in Australia: Mapping the Gaps Between the Harms Occasioned and the Remedies Provided' (2016) 39(2) University of New South Wales Law Journal 488 ('Mapping the Gaps'); Katharine Gelber and Luke McNamara, 'The Effects of Civil Hate Speech Laws: Lessons from Australia (2015) 49(3) Law and Society Review 631 ('Lessons from Australia'). See also Dilan Thampapillai, 'Managing Dissent under Part IIA of the Racial Discrimination Act (2010) 17(1) Murdoch University Electronic Journal of Law 52.

6 For a detailed examination of the legislative purpose for enacting pt IIA, see Bill Swannie, 'Protecting Victims Not Punishing Perpetrators: Clarifying the Purpose of s18C of the Racial Discrimination Act' (2020) 24(1) Media and Arts Law Review 24. In summary, the purpose of pt IIA is to protect members of target groups from racial vilification, to provide remedies to victims of such conduct, and to deter such conduct.

Part IIB of the AHRCA is titled 'Redress for Unlawful Discrimination'. 
legal rights and duties, between a victim and a wrongdoer, which is a central feature of corrective justice. ${ }^{8}$

Part III of this article argues that the remedial process currently fails to provide corrective justice to targets of racial vilification in two key respects. First, it fails to respect the autonomy of complainants, as it requires them to attempt conciliation before proceeding to adjudication. Attempting conciliation can be time-consuming and ultimately futile for complainants, particularly when the respondent is recalcitrant and well-resourced. Second, the remedial process strongly emphasises settlement of racial vilification complaints, rather than adjudication. Settlement, by its nature, is both voluntary and confidential. Adjudication, on the other hand, provides authoritative and public vindication for targets of racial vilification (which is, by definition, conduct that is both public and communicative). ${ }^{9}$

Part IV of this article recommends two legislative amendments that would address the two problems highlighted above, and which would promote corrective justice in cases of racial vilification. First, targets of racial vilification should have direct access to court for adjudication of a complaint, rather than being required to attempt conciliation in every case. This would respect a complainant's choice to seek an authoritative determination of their rights, rather than seeking voluntary settlement. Second, cost rules should be modified in respect of court proceedings for racial vilification. Currently, unsuccessful claimants may be ordered to pay a respondent's legal costs, and this may deter victims from seeking to vindicate their rights in court. This article argues that costs should be ordered only in limited circumstances, such as when a complainant commences proceedings vexatiously or has unreasonably caused a respondent to incur costs.

\section{CORRECTIVE JUSTICE AND REDRESS UNDER RACIAL VILIFICATION LAWS}

This Part of the article argues that corrective justice provides an appropriate framework for understanding the process by which victims of racial vilification may seek redress for that wrong. First, it outlines the provisions of pt IIA of the $R D A$, and the provisions in the AHRCA concerning redress. Second, it critically examines recent concerns regarding unmeritorious complaints, and the apparent need to resolve (or terminate) such complaints as quickly as possible. Third, this Part argues that corrective justice provides a suitable framework for evaluating

Corrective justice is examined in Part IIC below.

Racial vilification is similar to defamation in that it wrongfully undermines a person's public standing. See Bill Swannie, 'The Influence of Defamation Law on the Interpretation of Australia's Racial Vilification Laws' (2020) 26(1) Torts Law Journal 34. 
the process for seeking redress for breach of pt IIA. This is because pt IIA seeks to protect a legal right, and it imposes obligations on others not to infringe that right.

\section{A Part IIA and the AHRCA Remedial Process}

The substantive provisions of pt IIA consist of two operative parts. ${ }^{10}$ First, s 18C makes it unlawful to do an act that is 'reasonably likely, in all the circumstances, to offend, insult, humiliate or intimidate another person or a group of people', if the act is done 'because of the race' of the person or group of persons. ${ }^{11}$ Significantly, such conduct is unlawful only if it is done 'otherwise than in private'. ${ }^{12}$ Second, s 18D provides several exemptions from liability under s 18C. These exemptions provide defences for respondents, provided that they have acted 'reasonably and in good faith' for certain purposes. ${ }^{13}$ This article focuses on issues concerning redress for racial vilification. However, the substantive provisions of pt IIA, and the process for seeking redress, must be considered together. ${ }^{14}$

The process for seeking legal redress for an alleged breach of pt IIA is set out in the AHRCA, and involves two stages. A person 'aggrieved' by such conduct may make a complaint to the Australian Human Rights Commission ('AHRC'), ${ }^{15}$ and the AHRC may attempt to conciliate the complaint. ${ }^{16}$ In certain circumstances, the President of the AHRC may (or must) terminate the complaint. ${ }^{17}$ After a complaint is terminated, proceedings may be commenced in the Federal Court or the Federal Circuit Court. ${ }^{18}$

Three points should be emphasised regarding the remedial process set out in the AHRCA. First, only a person 'aggrieved' by the relevant conduct may make a complaint or commence proceedings in respect of that conduct. Therefore, the

For a background to the enactment of Part IIA, see, eg, Luke McNamara, Regulating Racism: Racial Vilification Laws in Australia (Sydney Institute of Criminology, 2002). For a critical analysis, see Dan Meagher, 'So Far So Good?: A Critical Analysis of Racial Vilification Laws in Australia' (2004) 32(2) Federal Law Review 225. relevant case law.

Part IIB2 of this article examines this requirement in detail.

For an analysis of the requirements of the exemptions in s18D, see Bropho $v$ Human Rights and Equal Opportunity Commission (2004) 204 ALR 761.

For example, the Freedom of Speech Report (n 3) examined both the substantive provisions in pt IIA of the RDA and the associated procedures in the AHRCA.

AHRCA s 46P.

Ibid s 46PF.

Ibid s 46PH.

Ibid s 46PO. 
remedial process is entirely complaint-driven, in that only victims of racial vilification can take action to seek a remedy. Conversely, the state has no role in enforcing these laws (apart from providing the legal framework). ${ }^{19}$ Therefore, the AHRCA provides a process by which victims of racial vilification may seek a remedy for the breach of their rights.

Second, the vast majority of complaints of racial vilification are either resolved or otherwise terminated at the AHRC stage, and very few complaints proceed to adjudication by a court. ${ }^{20}$ The process set out in the AHRCA is intended to promote settlement of complaints rather than resolution by adjudication. Amendments to the AHRCA in 2017 introduced further barriers to adjudication, such as a requirement to seek leave before commencing proceedings. ${ }^{21}$

Third, the remedial process set out in the AHRCA applies to all types of complaint made under Commonwealth anti-discrimination legislation.22 Therefore, the process does not distinguish between racial vilification complaints and other complaints of discrimination. However, this article argues that conduct that breaches pt IIA is qualitatively different to other types of discrimination. In particular, such conduct is by definition both public and communicative. Therefore, conciliation, which is private and confidential, may not provide proper vindication of the complainant's rights. Particularly when viewed from a corrective justice perspective, this supports the argument made in Part IV of this article, that attempting conciliation should be optional, rather than mandatory, for racial vilification complaints.

\section{B Disagreement as to the Purpose of the AHRCA Process}

Currently, there are widely divergent views as to the purpose of the AHRCA process. On the one hand, scholars such as Gelber and McNamara argue that the process is risky and burdensome for complainants, and that the state should

19 Gelber and McNamara (n 4) argue that the state should have a role in enforcing racial vilification laws, as they argue that it is a public wrong.

$20 \quad$ Ibid 501. See Australian Human Rights Commission, Complaint Statistics 2019-2020 (2020) 22-6. See http://humanrights.gov.au/sites/default/files/2020-10/AHRC_AR_2019-20_Complaint Stats_FINAL.pdf

21 The Human Rights Legislation Amendment Act 2017 (Cth), which commenced on 13 April 2017, amended the AHRCA by requiring complainants to obtain leave before commencing proceedings. It also emphasised the costs risks for complainants in commencing proceedings. Part IIA and B of this article examine these amendments.

22 Racial vilification is defined as a type of 'unlawful discrimination' under pt IIB of the AHRCA. See the definition of 'unlawful discrimination' in AHRCA s 3(1). The four federal discrimination Acts to which the AHRCA process applies are the RDA, the Sex Discrimination Act 1984 (Cth), the Disability Discrimination Act 1992 (Cth), and the Age Discrimination Act 2004 (Cth). 
enforce these laws, rather than individuals. ${ }^{23}$ Their work highlights the importance of having a clear conceptual framework for understanding the process for resolving racial vilification complaints. Having this framework enables a fair evaluation of current processes and suggested 'improvements'.

On the other hand, the Freedom of Speech in Australia report, published in 2017, emphasises concerns regarding unmeritorious complaints and the importance of resolving such complaints quickly and efficiently. ${ }^{24}$ The report, and subsequent amendments, emphasise concerns regarding trivial, vexatious and otherwise unmeritorious complaints, or those having 'no reasonable prospect of success' ${ }^{25}$ In particular, the report emphasises the importance of efficient and timely resolution (or termination) of such complaints, and the cost, inconvenience and distress that such complaints cause to respondents.

The report also emphasises the costs to the public of attempting to resolve trivial and vexatious complaints, both at the AHRC stage and particularly when such complaints proceed to adjudication. ${ }^{26}$ The report emphasises the importance of terminating trivial and vexatious complaints at the earliest opportunity, and preventing such complaints from proceeding to adjudication by a court. ${ }^{27}$

In 2017, the AHRCA was amended, based on recommendations made in the Freedom of Speech report. ${ }^{28}$ Following the amendments, the AHRC must terminate a complaint (and not attempt conciliation) when the President considers the complaint 'trivial, misconceived, vexatious or lacking in substance', ${ }^{29}$ or if there is no reasonable prospect that a court would determine that the conduct alleged is unlawful. ${ }^{30}$ In addition, the amendments require leave of the court to commence proceedings under the AHRCA, ${ }^{31}$ and courts are specifically directed, when determining costs in a proceeding, to have regard to any settlement offers

23 Gelber and McNamara (n 4).

24 Freedom of Speech Report (n 3).

25 Ibid ch 3 ('Complaint Handling at the Australian Human Rights Commission').

26 Ibid [3.149]-[3.152].

27 The Freedom of Speech Report (ibid [3.84]-[3.92]) refers extensively to the complaint and proceedings in Prior $v$ Queensland University of Technology [2016] FCCA 2853. This proceeding was ultimately dismissed by the Federal Circuit Court of Australia as having no reasonable prospect of success. The case was, however, unusual and complicated, in that it involved several respondents, including the applicant's employer. The proceeding was dismissed on a number of grounds, including that the applicant was unable to prove that statements made on one respondent's social media account were in fact made by that person. Despite the Report's emphasis on this case, there is little evidence of a large number of trivial or vexatious racial vilification complaints, or that these cases are more difficult or costly for courts to resolve than any other type of proceeding. Human Rights Legislation Amendment Act 2017 (Cth).

AHRCA s 46PH(1B).

Ibid $s$ 46PH(1C). Previously, the President had discretion to terminate complaints in these circumstances.

Ibid s 46PO(3A). Previously, proceedings could be commenced under the AHRCA without leave. 
made. ${ }^{32}$ The AHRCA also directs the President, when terminating a complaint, to advise complainants that courts 'can award costs in a proceeding'. ${ }^{33}$

The amendments sought to improve the 'efficiency' of the complaint resolution process, by preventing 'unmeritorious' complaints from proceeding to court. ${ }^{34}$ The emphasis, therefore, was on the efficient and timely resolution of racial vilification complaints, and the cost, inconvenience and distress caused to respondents in responding to a complaint. ${ }^{35}$ However, this emphasis appears to overlook the perspective of complainants - those whom pt IIA seeks to protect. More significantly, these justifications assume, rather than articulate, a conceptual framework for evaluating the operation of the remedial processes in the AHRCA. The next section will argue that corrective justice provides an appropriate framework.

\section{Corrective Justice Provides an Appropriate Framework}

This section argues that corrective justice provides an appropriate framework for understanding the process for resolving complaints of racial vilification. In broad terms, corrective justice provides that a person whose legal rights have been infringed is entitled to an appropriate legal remedy, or redress, for that wrong. Therefore, corrective justice stands in strong contrast to an approach that focuses primarily on the rights and interests of respondents, or which emphasises the need to resolve disputes quickly and efficiently. Rather, corrective justice explicitly emphasises the rights and interests of claimants, or victims of a legal wrong.

This section first outlines relevant aspects of corrective justice and civil recourse theory. Second, it argues that corrective justice properly applies to the civil wrong of racial vilification. Finally, the section summarises the importance of corrective justice to the process for resolving complaints of racial vilification.

\section{Corrective Justice and Civil Recourse Theory}

Corrective justice concerns the rectification of interpersonal wrongs, to ensure that the victim of a legal wrong is made 'whole again', or restored to their former

Ibid s 46PSA. According to standard costs rules, a party will be ordered to pay the other party's legal costs (often on an indemnity basis), if they refuse a reasonable offer of settlement and they do not achieve a more favourable order. Section IV(B) of this article examines the costs rules. AHRCA s $46 \mathrm{PH}(2 \mathrm{~A})$

Explanatory Memorandum, Human Rights Legislation Amendment Bill 2017 (Cth) 11.

The Explanatory Memorandum stated (ibid 4) that these changes made the process 'fairer for all parties', as the current process is 'weighted in favour of complainants'. On the other hand, Gelber and McNamara (n 4) argue that the AHRCA process is extremely burdensome for complainants. 
position. ${ }^{36}$ Aristotle's influential articulation of corrective justice emphasised the primary role of 'the judge' in restoring the balance as between a person who had been wronged and the wrongdoer. ${ }^{37}$ Corrective justice therefore involves three entities: a claimant (whose rights have been infringed by the respondent), a respondent (who has infringed the claimant's rights), and the state. The justification for imposing a duty of rectification is simply that 'one person has been wronged, and the other has wronged them'. ${ }^{38}$

Although corrective justice is primarily applied in the context of tort claims, it applies more broadly to any breach of an individual's legal rights. ${ }^{39}$ Further, corrective justice applies to civil wrongs even when there is no discernible 'gain' made by the wrongdoer..$^{\circ}$ Rather, the focus of rectification is on the victim, and what is needed to make this person whole again. Aristotle's principle of rectification is not merely purposed to providing financial recompense to the victim, but also extends to vindication of the claimant's rights..$^{41}$

Like correctice justice, civil recourse theory concerns the rectification of interpersonal wrongs. $4^{2}$ Three aspects of corrective justice, and civil recourse theory, are relevant in the context of this article. First, corrective justice emphasises the state's obligation to provide appropriate mechanisms for a victim to be made 'whole' again. Therefore, it is not concerned exclusively with particular remedies (ie the particular outcome ordered by a court). Rather, corrective justice also concerns the procedures used to resolve particular types of civil dispute. ${ }^{43}$ Indeed, vindication of a claimant's rights (eg through a judicial

36 Ernest Weinrib, 'Corrective Justice in a Nutshell' (2002) 52(4) University of Toronto Law Journal 349. As explained below, corrective justice imposes obligations on the wrongdoer and on the state.

37 Aristotle and WD Ross, Nicomachean Ethics (Lesley Brown (ed), Oxford University Press, 2009). Aristotle also used the term 'rectificatory justice'.

38 Ibid 1132a. Aristotle stated (ibid) that 'it makes no difference [to this justification] whether a good man defrauded a bad one, or a bad man a good one'. This is because, according to the logic of corrective justice, a wrongdoer is by definition a bad person. Aristotle distinguished corrective justice from distributive justice on the basis that the latter involved consideration of a person's merit, but the former was based purely on a wrong done by one person to another.

39 These types of claims are commonly described as 'civil', or 'private law', claims. See, eg, Ernest Weinrib, The Idea of Private Law (Oxford University Press, 1995). In the words of Aristotle, corrective justice applies to claims 'between man and man': Aristotle and Ross (n 37) 1131a.

$40 \quad$ Weinrib (n 36) 354-5.

41 Ibid. See also Linda Radzic, 'Tort Processes and Relational Repair' in John Oberdiek (ed), Philosophical Foundations of The Law of Torts (Oxford University Press, 2014) 248. In certain cases, corrective justice seeks to provide vindication, rather than compensation for loss. See Part III(B) of this article below.

42 Some aspects of civil recourse theory are referred to below. Although civil recourse theory and corrective justice are sometimes regarded as competing theories in respect of remedies for civil wrongs, the differences between these theories are not relevant for the purpose of this article, and are in any event 'gossamer thin': Ernst Wienrib, 'Civil Recourse and Corrective Justice' (2011) 39(1) Florida State University Law Review 273, 297.

43 Jason Varuhas, Damages and Human Rights (Bloomsbury, 2016) 88-9 ('Damages'). Although Varuhas does not refer specifically to corrective justice, his remedial theories are consistent with 
declaration or correction notice) may provide an appropriate remedy for wrongs such as racial vilification.

Civil recourse theory focuses particularly on procedural issues in private law. 44 This theory posits that the victim of a legal wrong merely has a legal right to seek a remedy in court (rather than, as some corrective justice theorists argue, a right to a particular remedy). 45 Therefore, both corrective justice and civil recourse theory emphasise the importance of procedural aspects of rights protection, and particularly the importance of access to courts for the vindication of individual rights. 46

Second, corrective justice focuses on the 'distinctive character of the injury' inflicted on the victim. 47 Therefore, the nature and features of the particular right infringed are key in determining appropriate modes of redress..$^{88}$ In relation to racial vilification, an important aspect of corrective justice is the public vindication of the claimant's rights. Scholars such as Varuhas argue that vindicating certain individual rights involves vindicating the interests - such as human dignity - underlying those rights. ${ }^{49} \mathrm{He}$ argues that this is necessary in order to 'restore the claimant to the position they were entitled to be in'. ${ }^{50}$

Third, civil recourse theorists emphasise the importance of a victim's autonomy, and they argue that a victim should be able to choose how they respond to a wrong committed against them. ${ }^{51}$ For example, a victim may decide to initiate proceedings, to settle those proceedings, or to make no claim at all. ${ }^{2}$

Corrective justice and civil recourse theory are both remedial theories, as they concern rights and duties regarding remedies for the breach of other substantive rights. Scholars such as Hohfeld describe remedial duties as 'secondary' duties,

the principles outlined here. In particular, Varuhas (at 89) argues that procedural restrictions, such as time limits for commencing a claim, are 'inapt in claims of fundamental rights, as they may impede robust judicial protection of those important rights'.

44 See, eg, Benjamin C Zipursky, 'Civil Recourse, Not Corrective Justice' (2003) 91 Georgetown Law Journal 695. See also John Goldberg and Benjamin Zipursky, 'Tort Law and Responsibility' in John Oberdiek (ed), Philosophical Foundations of The Law of Torts (Oxford University Press, 2014) 17.

$45 \quad$ Zipursky (n 44); Goldberg and Zipursky (n 44).

46 Part IIIB of this article highlights the importance of allowing claimants access to courts for redress for the wrong of racial vilification (which is by definition a public or communicative wrong).

Aristotle and Ross (n 37) v, 2-5, 1132.

Varuhas (n 43) viii.

Ibid 59 .

Ibid 22 .

Astor and Chinkin also emphasise the importance of 'empowering' victims of wrongdoing, particularly through providing effective means for resolving alleged contraventions of legal rights: Hilary Astor and Christine Chinkin, Dispute Resolution in Australia (LexisNexis, $2^{\text {nd }}$ ed, 2002) 382.

52 Goldberg and Zipursky (n 44). However, they also recognise that this choice represents a legal power that a victim has over a wrongdoer, which is backed by the coercive power of the state. 
as they depend on a prior breach of other 'primary' rights. ${ }^{53}$ Remedial theories are therefore underpinned by, and support, individual rights. Individual rights are in turn commonly based by notions of human dignity, personal autonomy and the state's obligation to treat every person with equal concern and respect.54 Remedial theories emphasise the importance of a victim of wrongdoing being able to take legal action to rectify that wrong. The right to seek rectification is based on, and gives meaning and force to, underlying legal rights, and it affirms the claimant's equal worth as a member of society. ${ }^{55}$ The right to seek rectification also supports a claimant's autonomy, as it enables them to choose what action to take, if any, in respect of the infringement of their rights.

Corrective justice, including its procedural and remedial aspects, is supported by principles of liberal democracy and the rule of law. The principle $u b i$ ius, ibi remedium - where there is a right, there must be a remedy - is foundational to a legal system based on the rule of law. ${ }^{56}$ Therefore, a core obligation of the state is to ensure that infringements of individual rights are adequately rectified, as without effective enforcement, rights are practically worthless. ${ }^{57}$ Therefore, there is both an individual interest and a public benefit in the effective enforcement of individual rights. ${ }^{58}$

\section{Corrective Justice Applies to Racial Vilification}

As mentioned above, corrective justice cogently explains how the law responds (or should respond) to a breach of individual legal rights. Further, there are particular reasons why corrective justice provides an appropriate theoretical framework for assessing the process for seeking redress for infringement of pt IIA of the RDA. These provisions include the three essential foundations for corrective

$53 \quad$ Wesley Hohfeld, 'Fundamental Legal Conceptions as Applied in Judicial Reasoning' (1917) 26(8) Yale Law Journal 710.

$54 \quad$ See, eg, Ronald Dworkin, Taking Rights Seriously (Harvard University Press, 1977). Dworkin's influential theory of rights is based on the centrality of individual dignity, and the democratic importance of the state treating every person with equal concern and respect. Dworkin's is a particularly strong theory of rights protection, as he argued (at 272) that the state must respect individual rights even if this would not benefit the community as a whole.

Varuhas (n 43) 1-18.

Ibid 3, 88. See also Olivia Ball, 'All the Way to the UN: Is Petitioning a UN Human-Rights Treaty Body Worthwhile?' (PhD Thesis, Monash University, 2017) ch 2.

Ball (n 56).

Therefore, Varuhas argues that the distinction between 'public' and 'private' law is unhelpful and 'unsafe' in relation to legal redress for the breach of individual rights: Varuhas ( $\mathrm{n}$ 43) 8. On the other hand, Gelber and McNamara (n 4) argue that the state, rather than individuals, should enforce pt IIA of the RDA, as they define this as a 'public wrong'. Like Varuhas, this article does not find the public/private distinction useful in relation to seeking redress for breach of individual rights. For example, civil wrongs (such as an assault) are commonly enforced by individuals through claims for damages. 
justice: they confer rights on individuals, they impose reciprocal duties on others, and they seek to provide redress when those rights are infringed. Also, when pt IIA was enacted, its protective and remedial purpose was emphasised.

In relation to duties, pt IIA (which consists of ss 18C and 18D) renders certain conduct 'unlawful'. In particular, s 18C defines and renders unlawful 'racial vilification' ${ }^{59}$ Further, s 18D provides certain exemptions (or defences) to liability under s $18 \mathrm{C} .{ }^{60}$ Therefore, pt IIA imposes a duty on all members of society to refrain from racially vilifying another person or group of persons. Significantly, pt IIA imposes civil liability only; there are no criminal consequences for infringing pt IIA. A complaint, or proceedings, alleging breach of pt IIA involves individual complainants and respondents, and the state has no active enforcement role or powers in relation to pt IIA. ${ }^{61}$

Regarding rights, the AHRCA provides that an 'aggrieved' person may make a complaint and seek a legal remedy regarding an alleged breach of pt IIA. Therefore, only a victim (or target) of racial vilification may seek a remedy in respect of a breach of pt IIA. ${ }^{62}$ In summary, the AHRCA confers a legal right on individuals to not be racially vilified. These rights and duties are reciprocal, or correlative, and therefore the claimant's right to seek a legal remedy can be considered a 'right' in the true sense. ${ }^{63}$

In terms of redress, the AHRCA provides certain legal remedies, where a court finds that a respondent has breached pt IIA. ${ }^{64}$ Therefore, a claimant is entitled to certain court orders when they establish that a particular person has breached pt IIA. In summary, therefore, pt IIA and the AHRCA provide the three essential elements for corrective justice to apply: a claimant with legal rights, a respondent with legal duties, and legal remedies.

Part IIA does not include the words 'racial vilification'. However, these words have been adopted as a 'convenient shorthand' for the type of conduct proscribed by s 18C: Toben $v$ Jones (2003) 129 FCR 515, [137] (Carr J).

60 Taken together, ss 18C and 18D have a two-part, tort-like structure. Section 18C defines conduct to which prima-facie liability attaches, for which the claimant bears the onus of proof. Section 18D provides defences to liability, for which the respondent bears the onus of proof. See generally Peter Cane, The Anatomy of Tort Law (Hart, 1997).

61 Gelber and McNamara (n 4) 328. Gelber and McNamara compare the neutral role of the AHRC to the active regulatory powers of the Australian Securities and Investments Commission, and the Environmental Protection Authority, for example (at 310-11).

62 A 'victim' may be a person who is directly named or identified in the relevant conduct, or a member of a particular racial or ethnic group vilified in the conduct. A person who is not 'aggrieved' by the relevant conduct has no standing to bring a complaint or commence proceedings: see Gelber and McNamara, 'Mapping the Gaps' (n 5) 497.

63 See Hohfeld (n 53). Hohfeld distinguishes between 'rights' (which can be claimed by a particular person against another person with a corresponding duty), and mere privileges and immunities (which are merely defensive legal proscriptions). 
Further, parliamentary debate when pt IIA was enacted confirms that these provisions were intended to provide legal protection and remedies to targets of racial vilification. When the relevant bill was introduced into Parliament, ${ }^{65}$ the Attorney-General stated that it would establish a 'civil regime' by which 'the victim of alleged unlawful behavior' could initiate a complaint and potentially obtain a remedy in relation to unlawful conduct. ${ }^{66}$

In particular, the Attorney-General emphasised the protective purpose of $\mathrm{pt}$ IIA, stating that 'all Australians irrespective of race, colour or national or ethnic origin are entitled to fair treatment', and that 'everyone should be able to advance through life on their own merits and abilities' ${ }^{67}$ He noted, however, that 'major inquiries have found gaps in the protection provided by the [RDA]', particularly regarding racially based harassment and intimidation. ${ }^{68}$ Referring to the Multiculturalism Report, ${ }^{69}$ the Attorney-General stated that protection from racial vilification 'protects the inherent dignity of the human person' ${ }^{70}$ This statement highlights the individual interests that pt IIA seeks to protect, which is consistent with enabling members of target groups to initiate a complaint and to potentially obtain a legal remedy..$^{71}$

The Attorney-General also emphasised the importance of education and changing attitudes regarding racism in Australia. ${ }^{72}$ However, these statements support, rather than detract from, the remedial and protective purposes for enacting pt IIA. Particularly where education programs focus on raising awareness concerning the provisions and operation of pt IIA, this supports the provision's protective purpose by seeking to deter and eliminate racial vilification. Deterrence of prescribed conduct is an important aspect of corrective justice, particularly in relation to the role of courts in educating the public regarding norms of acceptable conduct. ${ }^{73}$

Racial Hatred Bill 1994 (Cth).

Commonwealth, Parliamentary Debates, House of Representatives, 15 November 1994, 3341 (Michael Lavarch, Attorney-General) ('Commonwealth').

Ibid. The Attorney-General thus drew a direct connection between the various forms of racial discrimination already prohibited by the RDA and the prohibition on racial vilification introduced by the Racial Hatred Bill.

Ibid 3336-7. The three 'major inquiry' reports referred to by the Attorney-General are: Royal Commission into Aboriginal Deaths in Custody (Final Report, 15 April 1991) ('Royal Commission Report'); Commonwealth Human Rights and Equal Opportunity Commission, Report of the National Inquiry into Racist Violence in Australia (Report, 1991); Australian Law Reform Commission, Multiculturalism and the Law (Report No 57, April 1992) ('Multiculturalism Report').

Multiculturalism Report (n 68) [7.44].

Commonwealth (n 66) 3336.

In Bolt (n 11), Bromberg J (at [267]) stated that s 18C protects against 'conduct which invades or harms the dignity of the individual or group'.

Commonwealth (n 66) 3336.

See Varuhas (n 43) 19. 
Indeed, the Royal Commission Report emphasised that legislation such as pt IIA can itself can have a 'powerful educative role', particularly in relation to changing attitudes and 'defining [socially] acceptable behaviour' ${ }^{74}$ Logically, however, it is not merely legislation that educates and defines socially acceptable behaviour. Rather, it is court decisions that interpret and apply particular legislation and which define acceptable standards of behaviour. Therefore, the importance of corrective justice, and the redress provided by courts, is supported by parliamentary statements, when pt IIA was introduced, regarding the importance of public education and changing attitudes concerning racism.

Finally, the remedial and protective purpose of pt IIA is highlighted by the inclusion of $\mathrm{S} 18 \mathrm{E}$ in the RDA, which imposes liability on an employer for breach of s $18 \mathrm{C}$ by an employee, where the conduct is done 'in connection with his or her duties as an employee'. 75 Section $18 \mathrm{E}(2)$ provides that an employer is not liable if it took 'all reasonable steps to prevent the employee from doing the unlawful act'. Imposing vicarious liability on an employer, in addition to the primary wrongdoer, assists complainants in obtaining an effective remedy. ${ }^{76}$ In particular, $\mathrm{S} 18 \mathrm{E}$ enables an employer to be joined as a respondent to a complaint. Scholars have noted that s 18E may assist complainants particularly in relation to 'media organisations which may face liability for the actions of their journalists and announcers'. ${ }^{77}$ Consistently, over time, a large number of complaints of racial vilification involve conduct by media presenters, ${ }^{78}$ and $\mathrm{s} 18 \mathrm{E}$ has been raised in these complaints. ${ }^{79}$ In particular, s $18 \mathrm{E}$ enables court orders to be made against both the employee journalist or presenter and the employer publisher or broadcaster. ${ }^{80}$

\section{Summary}

In summary, this Part of the article has argued that corrective justice affords an appropriate framework for evaluating the process provided by the AHRCA for providing redress for racial vilification. Corrective justice provides that a person whose legal rights have been infringed is entitled to an appropriate remedy, or

Royal Commission Report (n 68) [28.3.1].

Commonwealth (n 66) 3341.

See, eg, Hollis v Vabu Pty Ltd (2001) 207 CLR 21, in which the High Court held that a bicycle courier service was vicariously liable for an injury caused to a pedestrian by the negligence of a bicycle courier.

Neil Rees, Simon Rice and Dominque Allen, Australian Anti-discrimination and Equal Opportunity Law (Federation Press, $3^{\text {rd }}$ ed, 2018) 729.

See McNamara (n 10) 153.

See, eg, Bolt (n 11) [66], [453].

Ibid. In Bolt, the newspaper publisher was ordered to publish a corrective notice in its newspaper and on its website. 
redress, for that wrong. Further, it obliges the state to rectify the wrong. This Part has demonstrated that pt IIA of the RDA confers correlative rights and duties with respect to racial vilification. In particular, a person 'aggrieved' by conduct alleged to infringe pt IIA is entitled to make a complaint and seek a legal remedy under the AHRCA. Therefore, corrective justice provides a more appropriate framework for evaluating the provisions of the AHRCA than approaches that emphasise economic efficiency, or which focus primarily on the rights and interests of respondents. This Part has also highlighted that corrective justice has an important procedural aspect. Indeed, certain court orders, such as the correction notice ordered by the Court in Eatock $v$ Bolt, may appropriately vindicate a claimant's rights. ${ }^{81}$

This Part provides the foundation for the remainder of this article, which examines whether the relevant provisions of the AHRCA are consistent with providing corrective justice regarding racial vilification complaints.

\section{Does the AHRCA Process Provide CoRrective JUSTICE?}

This Part of the article examines whether the AHRCA process enables targets of racial vilification to achieve corrective justice. Ultimately, it determines that the process fails to provide corrective justice in two key respects. First, it fails to respect the autonomy of claimants, as it requires them to attempt conciliation (which may be futile and time-consuming) before proceeding to adjudication of a complaint. Second, the current process strongly emphasises the settlement of racial vilification complaints, rather than adjudication. Therefore, it may prevent claimants from public vindication and an authoritative determination of their rights. These two arguments are examined, respectively, in sections A and B of this Part.

\section{A Compulsory and Voluntary Conciliation}

A large body of legal scholarship exists on the effectiveness, and appropriateness, of conciliation in the context of anti-discrimination complaints. ${ }^{82}$ In addition, scholars such as Gelber and McNamara argue that conciliation does not recognise the public wrong of racial vilification. ${ }^{83}$ This article does not argue against

81 In Bolt (n 11), the complainants sought an order that the respondent newspaper publish a public notice of the Court's finding. This remedy is examined in Part IIIB3 below.

82 See, eg, Margaret Thornton, The Liberal Promise: Anti-Discrimination Legislation in Australia (Oxford University Press, 1990) ch 5 ('Liberal Promise'); Beth Gaze and Rosemary Hunter, Enforcing Human Rights in Australia: An Evaluation of the New Regime (Themis Press, 2010) ch 8 \& 9. ('Enforcing Human Rights'); Astor and Chinkin (n 51); Anna Chapman, 'Discrimination Complaint-Handling in NSW: The Paradox of Informal Dispute Resolution' (2000) 22(3) Sydney Law Review 321. 
conciliation of racial vilification claims per se. Nor does it argue that all such claims should be adjudicated by a court. Rather, this section argues that claimants should have a choice as to whether they attempt conciliation on the one hand, or proceed to adjudication on the other. This argument is based on corrective justice and in particular on the importance of protecting the personal autonomy of victims of racial vilification.

This section first examines the concept of personal autonomy, and its importance in the context of dispute resolution. Second, it argues that, given the significance of personal autonomy, compulsory conciliation is not appropriate for complaints made under the AHRCA.

\section{Personal Autonomy and Redress for Civil Wrongs}

Personal autonomy is of central importance to civil recourse theory, which argues that a victim of a wrong should be able to choose how they respond to that wrong. ${ }^{84}$ Civil recourse theorists, such as Goldberg and Zipursky, emphasise the importance of a victim's ability to choose how to respond to a wrong committed against them. In particular, they argue that victims should be able to choose whether to litigate, to settle a claim, or to do nothing. ${ }^{85}$ They also emphasise the role of the state, which is to 'empower' victims to seek a legal remedy for wrongs committed against them. ${ }^{86}$

Corrective justice and civil recourse theory are underpinned by values such as human dignity and autonomy ${ }^{87}$ Personal autonomy is central to the protection of individual rights, which is an important role of the liberal democratic state. ${ }^{88}$ Some key aspects of personal autonomy will now be outlined.

Autonomy concerns a person's ability to make choices over their life, free from 'external' control or interference. ${ }^{89}$ Significantly, autonomy involves both a mental aspect (deciding what is in one's interests) and an active aspect (being able to act on that decision). ${ }^{90}$ Autonomy is underpinned by notions of human

Goldberg and Zipursky (n 44).

Ibid. Therefore, they regard victims as having a legal power - to demand responsive action from a respondent - rather than a legal right to a remedy (as argued by some corrective justice theorists). Ibid 29.

Varuhas (n 44).

Ibid 3, 78 .

See, eg, Thomas Scanlon, 'A Theory of Freedom of Expression' (1972) 1(2) Philosophy and Public Affairs 204. Scanlon regards autonomy as a 'universal moral value'. Although he emphasises autonomy in the context of free speech arguments, his broader arguments regarding the significance of personal autonomy, in relation to the state, are relevant here. Ibid. 
dignity and self-respect; if the state unduly restricts or undermines a person's autonomy, then it denies their human dignity. ${ }^{91}$

In their articulation of personal autonomy, scholars such as Scanlon and Nagel emphasise the significance of the relationship between the individual and the state. In particular, they argue that certain action by the state is improper or illegitimate because it interferes with a person's autonomy. These conceptions of personal autonomy therefore emphasise the role of the state in protecting and promoting autonomy, rather than (for example) emphasising other 'external' factors that may interfere with a person's autonomy. ${ }^{92}$

In summary, personal autonomy has an important role regarding the protection of individual rights, in particular regarding a victim's ability to choose to pursue avenues of redress that they consider suitable and appropriate. Civil recourse theorists particularly emphasise that persons who have had their legal rights infringed should have appropriate options as to how they respond to that wrong. Further, those options should be real and effective options, not merely formal options that are practically unavailable.

\section{Mandatory Conciliation Undermines a Complainant's Autonomy}

Currently, conciliation is mandatory for all complaints made under the AHRCA (ie complaints of racial vilification, and other complaints under anti-discrimination law). Therefore, a complaint must be made to the AHRC, and that complaint must be terminated, before proceedings can be commenced in respect of it. In this respect, the AHRC acts as a 'filter' for unmeritorious complaints. ${ }^{93}$ The President of the AHRCA may (or must) terminate particular complaints based on certain considerations. Many of these grounds for termination involve a determination by the President that a more appropriate forum is available for resolving the complaint. For example, a complaint may be terminated if the President determines that the 'subject matter of the complaint has been adequately dealt with', ${ }^{94}$ or that another 'more appropriate remedy ... is reasonably available', ${ }^{95}$ or that the 'complaint could be more effectively or conveniently dealt with by another statutory authority'. ${ }^{96}$

See Thomas Nagel, 'Personal Rights and Public Space' (1995) 24(2) Philosophy and Public Affairs 83, 93-6.

Other factors, such as a claimant's financial resources, may influence their choice regarding whether to commence proceedings. However, interference with this choice by the state stands in a different category, according to Nagel's and Scanlon's conception of autonomy.

Rees, Rice and Allen (n 77) 816.

AHRCA s 46PH(1)(d).

Ibid s 46PH(1)(e).

Ibid s 46PH(1)(g). 
Therefore, even the most serious complaints of racial vilification, and those which are unlikely to settle at conciliation, must first be processed by the AHRC. The AHRCA itself acknowledges that some complaints are not appropriate for conciliation, but are more appropriately determined by a court. For example, one ground for termination is that 'the President is satisfied that the subject matter of the complaint involves an issue of public importance that should be considered by the Federal Court or the Federal Circuit Court'. ${ }^{97}$ Similarly, a complaint may be terminated if the President is satisfied that there is 'no reasonable prospect of the matter being settled by conciliation' ${ }^{98}$ However, even these types of complaint must first be made to the AHRCA, and terminated, before proceedings can be commenced.

Several arguments are commonly presented as to why conciliation is preferable to adjudication in relation to anti-discrimination complaints. ${ }^{99}$ In summary, it is argued that conciliation has the advantages of quickness, informality, flexibility, confidentiality, and that it helps to maintain ongoing relationships (eg in the employment context). Clearly, in certain circumstances, conciliation may be a useful and effective method for resolving a dispute. However, the issue considered here is whether compulsory conciliation is consistent with respecting the autonomy of victims of racial vilification.

In particular, scholars have highlighted that attempting conciliation can be futile, and it can simply delay resolution of a complaint, due to two main factors. First, conciliation is a voluntary process, the aim of which is to settle a claim by agreement. ${ }^{100}$ As it is voluntary, respondents cannot be compelled to make serious efforts at settlement. Indeed, respondents may use this stage to delay resolution of a complaint. ${ }^{101}$ Second, in relation to discrimination (and vilification) complaints, there is often a large disparity between the resources and knowledge of complainants and respondents, respectively. Specifically, respondents are typically better resourced and more experienced regarding legal processes than complainants. ${ }^{102}$ This gives respondents a distinct advantage regarding negotiating a settlement, particularly given the informal nature of conciliation.

Therefore, there are legitimate reasons why a complainant may seek to have a complaint adjudicated, rather than attempting conciliation. However,

Ibid s 46PH(1)(h).

Ibid s 46PH(1B)(b). When a complaint is terminated on either of these grounds, leave is not required for proceedings to be commenced based on the complaint: AHRCA s 46PO(3A). Therefore, these two grounds for termination stand apart from the other grounds, all of which require leave before proceedings can be commenced.

See, eg, Thornton (n 82); Astor and Chinkin (n 51) ch 11. See also Beth Gaze and Rosemary Hunter, Enforcing Human Rights in Australia: An Evaluation of the New Regime (Themis Press, 2010), and Dominique Allen, 'Behind the Conciliation Doors: Settling Discrimination Complaints in Victoria' (2009) 18(3) Griffith Law Review 776.

Astor and Chinkin (n 51).

See Gelber and McNamara (n 4).

Astor and Chinkin (n 51) 364. 
currently, complainants must attempt conciliation before commencing proceedings. The extent to which the requirement to attempt conciliation interferes with a claimant's autonomy (and particularly their choice regarding how they respond to the wrong of racial vilification) is highlighted by two additional factors.

First, the process set out in the AHRCA is unique among civil wrongs in that it requires a complaint to be made to an administrative body, and terminated by that body, before it can proceed to adjudication. In relation to other civil wrongs, such as claims in contract or tort, conciliation is not compulsory in this way. In addition, Astor and Chinkin note that discrimination complaints are often factually and legally complex, and that for various reasons (including cultural differences) they are 'not easy to resolve'. ${ }^{103}$ Therefore, such complaints may not necessarily be quickly and easily resolved by conciliation. ${ }^{104}$

Second, since 2011, discrimination complainants in Victoria have the option of either attempting conciliation or proceeding directly to adjudication by a tribunal. ${ }^{105}$ Previously, attempting conciliation was compulsory in Victoria. However, optional conciliation was introduced following a detailed inquiry and report into procedures under discrimination law in that state, which specifically recommended allowing direct access to adjudication. ${ }^{106}$ Therefore, this sets a precedent for making conciliation optional, rather than compulsory. Although the importance of a complainant's autonomy was not specifically referred to when the amendment was introduced, ${ }^{107}$ the amendment does in fact support complainant autonomy as articulated above. ${ }^{108}$

In summary, mandatory conciliation severely restricts a complainant's autonomy regarding how they choose to resolve a complaint of racial vilification

103 Ibid 367. Some discrimination complaints may not be factually or legally complex (or undisputed). However, it cannot be assumed that all such complaints are in this category.

104 Thornton also notes that singling out discrimination complaints for compulsory conciliation treats such wrongs as minor or trivial matters, rather than serious legal disputes that can proceed directly to adjudication: Thornton (n 82) 146.

105 See Equal Opportunity Act 2010 (Vic) s 122.

106 Department of Justice, Victoria, An Equality Act for a Fairer Victoria: Equal Opportunity Review (Final Report, 2008) 69.

107 The Attorney-General stated that allowing direct access provided a more effective and efficient process for resolving disputes: Victoria, Parliamentary Debate, Legislative Assembly, 10 March 2010, 786 (Rob Hulls, Attorney General).

108 There are significant differences between the Victorian regime and the federal regime for resolving discrimination matters. In particular, the Victorian tribunal is generally a costs-free jurisdiction, whereas the federal courts are costs jurisdictions. It is difficult to determine how many discrimination complainants are now applying directly to the Victorian tribunal, as these figures are not recorded by the tribunal or by the anti-discrimination commission. See Dominique Allen, Addressing Discrimination through Individual Enforcement: A Case Study of Victoria (Monash University, 2019) 15-16. 
(or discrimination). ${ }^{109}$ This is significant, as attempting conciliation may cause unnecessary delay, and be futile in any case. Therefore, mandatory conciliation cannot be regarded as consistent with central principles of corrective justice and civil recourse theory. Indeed, Astor and Chinkin argue that compulsory conciliation may be a 'hurdle[...] in the way of redress', and it may in fact deter complainants from proceeding with a complaint. ${ }^{110}$

\section{B The Public Nature of Racial Vilification Makes Compulsory Conciliation Inappropriate}

This section argues that racial vilification, as defined by pt IIA of the RDA, is 'public' in a way that makes compulsory conciliation inappropriate. Racial vilification is therefore different from other breaches of discrimination law, which do not necessarily involve conduct that is 'public' in this sense. Therefore, compulsory conciliation is not appropriate in cases of racial vilification, although it may be appropriatein respect ot other breaches of discrimination law.

This section first examines the central principle of corrective justice, that the redress provided must respond to the particular nature and features of the wrong. In relation to racial vilification, this indicates that the state should enable public vindication of the wrong done to a victim. Second, it examines the 'public' nature of racial vilification, in comparison to other breaches of discrimination law. Third, the section contrasts the public nature of vilification with the private and confidential nature of conciliation.

\section{Corrective Justice and the Importance of Appropriate Redress}

As outlined above, corrective justice emphasises the importance of rectifying the wrong done to a person. ${ }^{111}$ Specifically, it focuses on the 'distinctive character of the injury' inflicted on the victim. ${ }^{112}$ Rectification necessarily requires responding to the nature and features of the particular wrong. ${ }^{113}$

Scholars such a Varuhas emphasise the importance of public vindication in providing appropriate redress for particular wrongs. He argues that public vindication, by way of determination by a court, is an appropriate form of redress

Therefore, the arguments advanced in this section of the article logically apply to both racial vilification complaints and discrimination complaints. However, crucial differences between these two types of complaint are examined in the next section of the article.

Astor and Chinkin (n 51) 381.

See Part IIC above.

Aristotle and Ross (n 37) v, 2-5, 1132

Varuhas (n 43) viii. 
for wrongs such as defamation. ${ }^{114}$ This is because certain rights can be regarded as 'fundamental', and therefore the primary goal of redress is vindication, rather than compensation. ${ }^{115}$

Defamation is similar to racial vilification in that both involve 'public' conduct. ${ }^{116}$ Further, both defamation and racial vilification involve an attack on a person's public standing, or their dignity. The next subsection of this Part examines the 'public' nature of racial vilification, which is relevantly similar to defamation. Further, racial vilification is dissimilar to other breaches of discrimination law, which do not necessarily involve 'public' conduct. This highlights the importance of public redress for such conduct, to 'restore the claimant to the position they were entitled to be in'. ${ }^{117}$ The third subsection of this Part then turns to argue that the public nature of racial vilification is inconsistent with compulsory conciliation, which involves private settlement.

\section{The Inherently Public Nature of Racial Vilification}

As mentioned above, pt IIA of the RDA defines racial vilification and renders such conduct unlawful. However, such conduct is unlawful only where it is done 'otherwise than in private'. ${ }^{118}$ Therefore, scholars such as Gelber and McNamara emphasise that racial vilification inherently involves a public act. ${ }^{119}$

The requirement that the relevant conduct is done 'otherwise than in private' is partially defined by s $18 \mathrm{C}(2)$ and $18 \mathrm{C}(3)$. Section $18 \mathrm{C}(2)$ provides that

an act is taken not to have been done in private if it:

(a) causes words, sounds, images, or writing to be communicated to the public; or

(b) is done in a public place; or

(c) is done in the sight or hearing of people who are in a public place. ${ }^{120}$

Section 18 C(3) provides that 'public place' 'includes any place to which the public have access as of right or by invitation, whether express or implied and whether

$114 \quad$ Ibid.

115 Varuhas (ibid) argues (at 59) that defamation protects a 'fundamental' right, because it is actionable per se (without proof of loss). Therefore, it protects fundamental human interests, such as human dignity, for which no amount of monetary compensation is adequate.

$116 \quad$ Swannie (n 9).

117 Varuhas (n 43) 22.

118 RDA s 18C.

119 See Gelber and McNamara (n 4) 314. See also Gelber and McNamara, 'Mapping the Gaps' (n 5) 510. This is part of the reason why Gelber and McNamara argue that racial vilification is a 'public wrong', in the sense that the state (rather than individuals) should enforce the laws.

120 The words 'not to have been done in private' seem to mean the same as 'otherwise than in private'. The different wording is due to s $18 \mathrm{C}(2)$ being a deeming provision. See Anna Chapman and Kathleen Kelly, 'Australian Anti-Vilification Law: A Discussion of the Public/Private Divide and the Work Relations Context' (2005) 27(2) Sydney Law Review 203. 
or not a charge is made for admission to the place'. The precise scope and nature of the words 'otherwise than in private' is, however, unclear. ${ }^{121}$ In Korczac $v$ Commonwealth, ${ }^{122}$ it was noted that 'the RDA does not require the relevant acts to have occurred "in public" or "in a public place". What is required is that the acts occur "otherwise than in private".'123

Clearly, Parliament intended to exclude purely 'private' conversations and conduct. ${ }^{124}$ The requirement that racial vilification must happen in public, rather than in private, is therefore a key aspect of the wrong. ${ }^{125}$ Notably, in McLeod $v$ Power, ${ }^{126}$ Brown FM found that an exchange between the applicant and the respondent, in which the impugned statement was directed to the applicant alone, and which was not heard by or communicated to anyone else, was not done 'otherwise than in private'. ${ }^{127}$ Brown FM stated that this was the case even though the relevant conduct took place in a public place, such as a public street. ${ }^{128}$ Therefore, regardless of where the relevant conduct takes place, s $18 \mathrm{C}$ has been interpreted as requiring that a member of the public may be able to see or hear the relevant conduct.

This requirement is similar to the requirement in defamation law that defamatory matter be 'published' to at least one person other than the plaintiff. ${ }^{129}$ Defamation is therefore concerned with a person's public reputation, rather than merely hurt feelings or private embarrassment. Similarly, racial vilification is inherently communicative in nature. Similar to defamation, racial vilification centrally involves communication to other people. ${ }^{130}$ The requirement that the relevant conduct be done 'otherwise than in private' necessarily involves communicating something to 'the public'. This is evident, for example, in the provision of the RDA by which certain circumstances are taken 'not to have been done in private'. As mentioned above, this includes conduct that causes words, sounds, images or writing to be communicated to the public. ${ }^{131}$

$121 \quad$ Ibid.

122 [1999] HREOC 29.

123 Ibid [46]; approved in Amponsem v Laundry (Exhibition) Pty Ltd [2013] FCCA 1982, [70] (Lloyd-Jones $\mathrm{J})$ and McLeod $v$ Power (2003) 173 FLR 31, 41 [46] (Brown FM).

$124 \quad$ Explanatory Memorandum, Racial Hatred Bill 1994 (Cth) 1. See also Chapman and Kelly (n 120) 213.

$125 \quad$ Chapman and Kelly (n 120) 209.

126 (2003) 173 FLR 31.

127 Ibid 39. In other words, the statement was outside the scope of s 18C, as it was 'private'.

128 Ibid 42.

129 Pullman $v$ Walter Hill \& Co Ltd [1891] 1 QB 524.

130 This is particularly evident in s 18D, which exempts certain conduct from liability under s 18C where it constitutes a 'performance [or] exhibition', or a 'statement, publication, discussion or debate', or certain types of comments or reports.

131 RDA s 18(1)(a). In Bolt (n 11), Bromberg J (at [242]) applied principles of defamation law in interpreting and applying pt IIA of the RDA. 
The public nature of racial vilification distinguishes it from other breaches of discrimination law. In discrimination law, the relevant conduct must occur in certain defined areas of public life (such as the provision of employment, or goods or services). ${ }^{132}$ However, there is no general requirement in discrimination law that the relevant conduct occur publicly, and incidents of discrimination are unlawful even if done 'in private'. ${ }^{133}$ However, as highlighted above, it is a central requirement of racial vilification laws that the relevant conduct is done 'otherwise than in private'. Therefore, although compulsory conciliation may be appropriate for discrimination complaints, arguably it is not appropriate for resolving complaints of racial vilification. ${ }^{134}$

\section{Private Settlement May Not Provide Appropriate Redress}

The public and communicative nature of racial vilification stands in strong contrast to the private nature of conciliation at the AHRC. Negotiations and settlement reached at the AHRC are 'private' in three separate ways. First, a conciliation conference is 'to be conducted in private'. ${ }^{135}$ Second, nothing said in the course of conciliation is admissible in subsequent court proceedings. ${ }^{136}$ Finally, settlement agreements are typically confidential. ${ }^{137}$ This stands in strong contrast to court proceedings, which are typically held in public, ${ }^{138}$ and which result in a public determination. There may be very good reasons for conciliation to be conducted privately, such as enabling full and frank negotiation to occur, including the making of concessions and offers of settlement. ${ }^{139}$ This section does not question the value of conciliation in relation to certain types of disputes.

132 Rees, Rice and Allen (n 77) ch 2.

133 The distinction between 'public' and 'private' conduct may be difficult to make in certain circumstances. Also, some discrimination claims have a 'public' aspect to them in that they may affect other members of the community and not just the individual complainant. For example, complaints relating to access to goods and services where other members of the community with the attribute in question (such as race or disability) will also be affected. Therefore, it may be argued that these complaints are not suitable for compulsory conciliation either.

134 When pt IIA was inserted into the RDA in 1995, little consideration was given by Parliament to the appropriateness of conciliation for racial vilification complaints (as distinct from discrimination complaints). However, a dissenting view in the Multiculturalism Report (n 68) stated (at [7.48]) that 'to offer no more than conciliation ... would add to the trauma of victims'. AHRCA s 46PK(2).

Ibid s 46PKA(1).

See, eg, Dominique Allen, 'Behind the Conciliation Doors: Settling Discrimination Complaints in Victoria' (2009) 18(3) Griffith Law Review 776, 786-9. Confidentiality of settlement agreements is not required by the AHRCA, but it is commonly agreed to by the parties.

138 See, eg, Open Courts Act 2013 (Vic).

However, offers of settlement, if not accepted, are admissible in relation to costs: AHRCA s 46PSA. Also, privacy and confidentiality may minimise or prevent additional trauma and humiliation, particularly for complainants. This may, in turn, encourage victims to lodge complaints with the AHRC. See, eg, Thornton (n 82) 154; Astor and Chinkin (n 51) 377. 
Rather, it highlights the contrast between the inherently public nature of racial vilification and the private nature of conciliation and any settlement reached. ${ }^{140}$

This Part has highlighted two factors relevant to the appropriateness of certain processes for seeking redress for racial vilification. First, corrective justice, and particularly the principle that the redress provided should match the nature and features of the particular wrong. Second, the autonomy of the claimant should be respected, regarding how they choose to respond to a wrong. This Part has argued that compulsory conciliation is inappropriate on both of these grounds. Settlement at conciliation is private and confidential, and it does not appropriately correspond to the public nature of racial vilification. In relation to respecting a claimant's autonomy, the critical flaw with conciliation at the AHRC is its compulsory nature. Optional conciliation would support and promote complainant autonomy. However, complainants should not be required to attempt conciliation in every case.

Sometimes it is argued that racial vilification complainants merely want to be heard and acknowledged by their respondents, and that conciliation provides this opportunity. ${ }^{141}$ However, scholars such as Astor and Chinkin argue that this is based on unproven assumptions regarding what claimants want in terms of redress. ${ }^{142}$ Given the public occurrence of racial vilification, complainants may legitimately seek a more public form of redress in respect of that wrong.

Indeed, there is evidence that racial vilification complainants commonly seek a public or communicative form of redress, rather than other remedies (such as compensation, or a private apology). For example, in Eatock $v$ Bolt, ${ }^{143}$ the applicant sought an order that the respondent newspaper publish a public notice of the Court's finding. ${ }^{144}$ Scholars such as Gaze and Smith note that 'vilification cases are brought to ensure public condemnation of the speaker, and to vindicate the principle of equality', rather than to seek an award of damages. ${ }^{145}$ Empirical research by Gelber and McNamara confirms that members of groups who have been publicly vilified typically seek public vindication, through a court or tribunal

140 Private settlement also undermines the important purpose of improving public awareness of racial vilification laws.

Astor and Chinkin (n 51) 383.

Ibid.

Bolt (n 11).

Adrienne Stone describes this as an 'expressive remedy'. See Adrienne Stone 'The Ironic Aftermath of Eatock v Bolt' (2013) 38(3) Melbourne University Law Review 926, 938-40.

145 See Beth Gaze and Belinda Smith, Equality and Discrimination Law in Australia: An Introduction (Cambridge University Press, 2017) 196. See also Gelber and McNamara, 'Mapping the Gaps' (n 5) 509. 
hearing and determination, of the wrong committed against them. ${ }^{146}$ They note in particular the 'dissonance' between a scheme that requires conciliation (which is confidential) as a 'first call', despite the fact 'that it will often be ill-suited to achieving an effective remedy for the public wrong incurred'. ${ }^{147}$

\section{Legislative AmEndments that Would FACILITATE CORRECTIVE JUSTICE}

This Part of the article proposes two legislative amendments that would provide corrective justice for victims of racial vilification to a greater extent than current processes. First, claimants should have direct access to court for adjudication of a complaint, rather than being required to attempt conciliation first. While this builds on the arguments presented in Part III, it also emphasises the authoritative nature of court decisions (in contrast to the voluntary nature of conciliation). Second, cost rules should be modified in respect of court proceedings for racial vilification. Currently, unsuccessful applicants (and even successful applicants, in certain circumstances) may be ordered to pay the respondent's legal costs. The risk of a costs order may deter complainants from seeking vindication of their rights in court. Therefore, costs should be ordered only in limited circumstances, as outlined below.

\section{A The Importance of Access to Adjudication}

This section argues that access to adjudication for determination of racial vilification claims supports corrective justice in two main ways. First, adjudication provides authoritative determination of a claimant's rights. Conciliation, on the other hand, is a voluntary process aimed at resolving disputes quickly and cheaply. Second, adjudication assists in promoting awareness of the relevant provisions, which enables victims to be aware of their rights, and which may deter incidents of vilification.

Gelber and McNamara (n 4). In Creek v Cairns Post Pty Ltd [2001] FCA 1150, Kiefel J (at [34]) noted the importance of vindicating the applicant (an Indigenous woman) 'in the eyes of her community'. 


\section{Justice versus Efficiency}

In his influential article, 'Against Settlement', US legal scholar Owen Fiss criticises approaches to dispute resolution that emphasise efficiency over justice. ${ }^{148}$ In particular, he criticises modes of alternative dispute resolution ('ADR'), such as conciliation, that may be quick and cheap, but which may not provide 'justice', particularly for claimants. ${ }^{149}$ Fiss emphasises that adjudication and ADR serve entirely different purposes, although proponents of ADR often assert that both methods simply resolve disputes, and that ADR does this more quickly and cheaply than adjudication.

Fiss argues that adjudication involves courts authoritatively interpreting and applying laws, whereas ADR simply seeks to settle disputes by agreement between the parties. ${ }^{150}$ He argues that terms of settlement often reflect the relative power and financial resources of the respective parties, rather than the merits of a claim. ${ }^{151}$ Fiss particularly emphasises that, in certain circumstances, settlement of a claim is not a substitute for judgment by a court. ${ }^{152}$ This is because the 'authority of [court] judgments arises from the law', rather than from an agreement between two parties. ${ }^{153}$ Certain legislation, Fiss argues, seeks to promote important social values, and, therefore, claims made under these laws should have direct access to adjudication, ${ }^{154}$ rather than being required to attempt ADR. ${ }^{155}$ Fiss also argues that allowing direct access to court promotes a claimant's autonomy. ${ }^{156}$

Fiss does not argue that all legal claims should be determined by courts, rather than resolved by ADR. Rather, he argues that claimants should have direct access to court when a legal dispute involves a 'public interest' issue. ${ }^{157}$ In particular, this is when a legal dispute affects a large number of people, and when it seeks to challenge a serious social wrong such as racial inequality. ${ }^{158}$ Fiss emphasises the importance of the decision of the United States Supreme Court in

Owen M Fiss, 'Against Settlement' (1984) 93 Yale Law Journal 1073.

Ibid 1075. Fiss does not refer specifically to corrective justice in this article. However, his views therein are consistent with corrective justice as outlined in the present article.

Ibid 1087.

Ibid 1078. See also Marc Galanter, 'Why the "Haves" Come Out Ahead: Speculations on the Limits of Legal Change' (1974) 9(1) Law and Society Review 165.

Fiss (n 148) 1083.

Ibid 1080 .

Ibid 1087 .

Ibid 1086.

Ibid. Fiss's arguments are therefore consistent with this article's emphasis on the importance of promoting claimant's autonomy.

Ibid 1087.

Ibid 1089 
Brown v Board of Education of Topeka ('Brown'), ${ }^{159}$ in which the Court determined that racially segregated public schools were unconstitutional, and it ordered the desegregation of public schools in the United States. ${ }^{160}$

Fiss argues that legal disputes such as Brown are not suitable for settlement by agreement, for two reasons. First, such disputes are inherently unlikely to settle, as the parties have fundamentally opposed views on an appropriate outcome. ${ }^{161}$ Second, the public has an interest in the outcome of such disputes, as the claim seeks to promote the public good of racial equality. ${ }^{162}$ Therefore, although such claims may be brought by individuals, they promote the public interest, as they seek to promote a socially valuable goal (such as eliminating racial discrimination), and they potentially benefit a large number of people. ${ }^{163}$ Therefore, Fiss argues that such claims should be determined by courts rather than private settlement.

Fiss acknowledges that claimants who seek to vindicate their rights in court may face obstacles, for example due to their lack of financial resources. ${ }^{164}$ However, he argues that judges are obliged to ensure that proceedings are conducted fairly. ${ }^{165}$ Therefore, he argues that a claimant's lack of financial resources should not prevent them from presenting their claim to a court, and having it fairly heard and determined. ${ }^{166}$

Dominique Allen applies Fiss's arguments to Australian discrimination law. ${ }^{167}$ Allen emphasises the importance of judicial articulation and protection of claimants' rights. ${ }^{168}$ She argues that court decisions not only vindicate individual rights, but can also serve a range of broader social purposes - none of which can be achieved by private settlement. ${ }^{169}$ Allen emphasises the importance of claimants having direct access to court for adjudication of their rights according to law. ${ }^{170}$

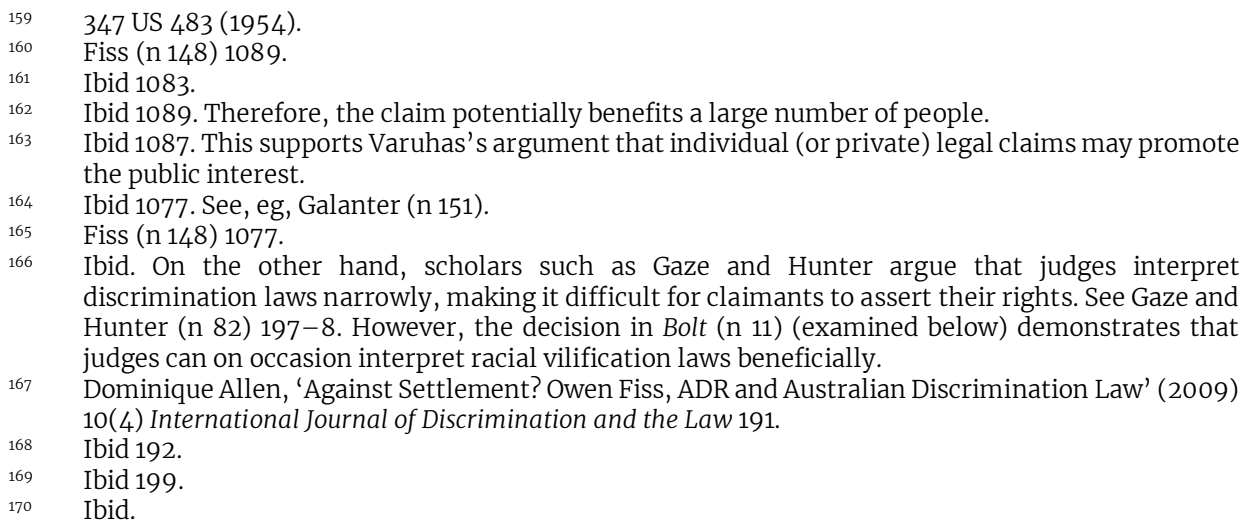
discrimination laws narrowly, making it difficult for claimants to assert their rights. See Gaze and Hunter (n 82) 197-8. However, the decision in Bolt (n 11) (examined below) demonstrates that judges can on occasion interpret racial vilification laws beneficially.

167 Dominique Allen, 'Against Settlement? Owen Fiss, ADR and Australian Discrimination Law' (2009) 10(4) International Journal of Discrimination and the Law 191.

Ibid 192.

Ibid 199.

Ibid. 
Fiss's and Allen's arguments can be applied to racial vilification laws. These laws seek to promote important social values, including protecting the autonomy of people subject to such conduct. Further, incidents of racial vilification may affect a large number of people and not merely the individual complainant. Therefore, there is a public interest in complainants having direct access to adjudication in respect of such claims..$^{171}$

\section{Conciliation at the AHRC Does Not Authoritatively Determine Claims}

Whereas courts have the power to authoritatively determine legal claims, the AHRC is an administrative agency with limited powers. It is not a court ${ }^{172}$ and has very limited coercive powers. Although it can require the attendance of certain people at conciliation, ${ }^{173}$ and the production of certain documents, ${ }^{174}$ it cannot compel a respondent to cooperate in seeking resolution of a complaint. Further, the AHRC cannot make any orders (such as costs orders) in favour of a complainant, and it cannot determine whether a complaint has been established, or order a respondent to provide any remedies. ${ }^{175}$ The AHRC is limited to assisting the parties to resolve a complaint by agreement. ${ }^{176}$

Further, unlike court processes, participation in conciliation is inherently voluntary in nature. ${ }^{177}$ Therefore, the efficacy of conciliation conducted by the AHRC depends almost entirely on the good faith and cooperation of the parties, and, in particular, on respondents. ${ }^{178}$ The AHRC can do very little - apart from terminating the complaint - in the face of an uncooperative respondent. Therefore, there is very little reason for a well-resourced respondent to participate in conciliation.

\section{Adjudication Promotes Awareness of Racial Vilification Laws}

Another reason for allowing direct access to courts for racial vilification claims is that adjudication promotes awareness of the law. ${ }^{179}$ Increased awareness of the law supports corrective justice in several ways. First, it enables those subject to

For further discussion of the 'public interest' aspect of racial vilification claims, see Part IV(B)(2) below.

Brandy v Human Rights and Equal Opportunity Commission (1995) 183 CLR 245.

AHRCA s 46PI.

Ibid.

Freedom of Speech Report (n 3) [3.24].

Ibid [3.23], [3.87].

Astor and Chinkin (n 51).

Freedom of Speech Report (n 3) [3.83].

Awareness of certain laws is, of course, also promoted by other types of educative programs, such as school-based programs and other awareness-raising programs. 
racial vilification to be aware of their right to seek redress. Second, it may deter would-be racial vilifiers from engaging in such conduct. Third, it serves the underlying purpose of civil liability, which is to establish and reinforce norms of behaviour. These three reasons will now be examined in greater detail.

First, the importance of promoting public awareness of the provisions of $\mathrm{pt}$ IIA of the RDA was emphasised when it was introduced into Parliament. ${ }^{180}$ Raising public awareness also supports the forms of legal redress provided by the provisions. In particular, court decisions provide an important form of education regarding particular laws. This is because court proceedings are generally held in public, and the public can attend hearings and the media can report on proceedings. ${ }^{181}$ Court decisions are publicly available, and this assists in making laws and their interpretation publicly known. Further, this enables members of the public to become aware of their rights and duties under the law. ${ }^{182}$ Conciliation, on the other hand, is conducted privately and therefore cannot promote awareness of racial vilification laws. ${ }^{183}$

Awareness-raising, and the importance of access to adjudication, supports corrective justice by enabling members of groups targeted by racial vilification to be aware of their right to seek redress. People cannot exercise their rights, or seek redress, unless they are aware of their rights under law. Significantly, the Freedom of Speech report noted that 'communities targeted by racial vilification were not aware of the laws or the process for making a complaint'. ${ }^{184}$ Media coverage of court hearings can generate public discussion of racial vilification and promote greater understanding of its harms. ${ }^{185}$ The educative effect of court decisions may have a wider reach, and greater impact, than formal education programs (eg in

$180 \quad$ See Part II(C)(2) above.

${ }_{181}$ As noted above, some respondents in racial vilification proceedings are themselves media presenters.

$182 \quad$ Gaze and Smith (n 144) 187.

183 This is despite strong assertions to the contrary by the AHRC. For example, in its 2018-19 annual report, the AHRC states that ' $80 \%$ of surveyed participants indicated that involvement in the complaint process had assisted them to better understand their rights and responsibilities under federal human rights and anti-discrimination law': AHRC, Complaint Statistics 2018-2019< http://humanrights.gov.au/sites/default/files/2019-10/AHRC_AR_2018-19_Stats_Tables_\%28 Final\%29.pdf> 25 ('Chart 6: Racial Discrimination Act - Outcomes of Finalised Complaints'). However, the limited extent of this 'educative' effect is apparent, in that it relates only to people who are already involved in the AHRC dispute resolution process.

184 Freedom of Speech Report (n 3) [4.11].

185 Tamsin Solomon, 'Problems in Drafting Legislation against Racist Activities (1994) 1(1) Australian Journal of the Human Rights 265, 277. The educative function of court hearings and decisions, of course, depends on adequate and accurate media reporting on such decisions. Given that prominent media commentators have been respondents in racial vilification proceedings, this can sometimes present difficulties. See, eg, Stone (n 144), who notes that a prominent media commentator who was found to have breached pt IIA subsequently used his position to publicly criticise, and misrepresent, the Court's decision and the provisions of pt IIA. However, courts have powers to punish for contempt of court in such circumstances. 
schools). ${ }^{186}$ This is because determinations made by a court carry significant weight and authority, particularly compared to decisions made by an administrative agency such as the AHRC.

Second, awareness-raising may deter would-be racial vilifiers from engaging in such conduct. This is because such people would be made aware, by the publicity and public debate surrounding court proceedings for racial vilification, of the consequences of breaching such laws. Similar to defamation laws, the consequences of breaching racial vilification laws are both financial and reputational. ${ }^{187}$ Deterrence of particular conduct may be considered the domain of criminal law. However, deterrence is not confined exclusively to criminal law. The law of civil wrongs also seeks to deter certain conduct, by imposing civil liability on individuals who breach those laws. ${ }^{188}$

Finally, awareness-raising (particularly through the publicity of court proceedings) serves the underlying purpose of civil liability, which is not merely to provide redress to individual claimants, but also to establish and reinforce norms of behaviour. As mentioned earlier, corrective justice is based on, and supports, the importance of underlying rights. ${ }^{189}$ Although duties of rectification are owed only by the wrongdoer to the victim, primary rights impose duties on every member of society. ${ }^{190} \mathrm{Also}$, the duty to respect primary rights is prospective, in that it guides future conduct (rather than merely providing rectification after a wrong is committed). Therefore, the decisions of courts in determining individual claims regarding civil wrongs serve an important normative and symbolic function in educating and reminding every member of society of their duties towards others under particular laws. ${ }^{191}$

The decision of Bromberg J in Eatock $v$ Bolt ('Bolt') ${ }^{192}$ illustrates these aspects of corrective justice. The decision promoted awareness of the provisions of pt IIA of the RDA, and highlighted the consequences for respondents of breaching those provisions. The decision vindicated the rights of the applicants, demonstrating

\footnotetext{
186 See, eg, Freedom of Speech Report (n 3) [2.137].

187 Swannie (n 9).

188 Gelber and McNamara (n 4). Peter Cane (n 60) notes (at 52) that breach of tort law involves not merely liability to pay compensation, but also a degree of 'moral stigma'. Therefore, although punishment (and deterrence) is not the primary purpose of tort law, it is an important secondary purpose: ibid 62.

189 See Part IIC2 above.

$190 \quad$ Hohfeld (n 53). See also Varuhas (n 43) 16.

191 See, eg, Cane (n 60). Cane argues that tort law serves two purposes, which are interlinked. First, it provides redress to individuals who have been wronged. Second, it provides general guidance to citizens: ibid 38. He particularly emphasises the role of courts in fulfilling both of these purposes: ibid 42.

192 Bolt (n 11).
} 
that those rights can and will be upheld in court.193 The applicants in Bolt were Indigenous Australians, who are typically marginalised in the Australian legal system. The two respondents, on the other hand, were a prominent media commentator and a powerful media company. Nevertheless, the applicants were successful in having their claim upheld by the Court. In doing so, the Court's decision clarified that pt IIA is not limited to overtly racist epithets or abuse, and that subtle or sophisticated denigration of members of a particular racial or ethnic group may contravene that Part. ${ }^{194}$

Court decisions can promote public awareness of certain legal principles. For example, in Brown, ${ }^{195}$ the United States Supreme Court ordered the desegregation of public schools in the United States, ${ }^{196}$ and in Mabo $v$ Queensland [No 2], ${ }^{197}$ the High Court of Australia recognised the existence of native title under Australian common law. ${ }^{198}$ The Bolt decision may be compared to these two famous decisions, in that it prompted public discussion and debate regarding racial vilification laws.

It may be argued that court proceedings have an educative effect only if the applicant is successful in the proceeding. However, Gelber and McNamara argue that '[1]itigation may ... have an educative effect, even where the conduct in question is ruled not to constitute [vilification].' ${ }^{199}$ This statement is based on empirical studies, including interviews by the authors with applicants in vilification proceedings. ${ }^{200}$ On this basis, Gelber and McNamara conclude that 'litigation is worth pursuing because it afford[s] [applicants] an opportunity, including via associated media coverage, to promote debate' about the harms of public vilification. ${ }^{201}$

Although the Bolt decision prompted broad-ranging debate concerning Australia's racial vilification laws, not all of this discussion accurately described either the relevant laws or the reasons for the Court's decision. ${ }^{202}$ However, this debate at least made the public aware of the existence of these laws, and of the relative importance of competing arguments, such as free speech. Therefore,

$194 \quad$ Bolt (n 11) [207].

195347 US 483 (1954).

$196 \quad$ Fiss (n 148) 1089.

197 (1992) 175 CLR 1.

198 The decision in Mabo $v$ Queensland [No 2] was based partly on considerations that included the importance of eliminating racial discrimination, in the form of the doctrine of terra nullius, from Australian common law.

199 Gelber and McNamara, 'Lessons from Australia' (n 5) 654.

200 This particular interview concerned homosexuality vilification; however, the point is applicable to racial vilification also.

201 Gelber and McNamara, 'Lessons from Australia' (n 5) 655.

202 
adjudication of racial vilification claims, and associated media coverage, assists in promoting awareness of racial vilification laws. In particular, Gelber and McNamara's research confirms that members of communities subject to racial vilification, such as Indigenous Australians, regard racial vilification laws as an important form of standard-setting. ${ }^{203}$ In other words, the ability to enforce such laws through the courts assists in setting standards of acceptable conduct by others. This provides a sense of protection and reassurance for members of vulnerable communities. ${ }^{204}$ As mentioned above, the protection of the rights and interests of victims of a legal wrong is an important aspect of corrective justice. The ability to seek redress in court emphasises the equal worth of targets of vilification, as the state has 'drawn a line in the sand distinguishing between acceptable and unacceptable public behaviour' ${ }^{205}$ Therefore, considering the importance of access to adjudication for racial vilification complaints, Parliament should provide direct access for complainants.

\section{B Costs}

This article has emphasised the importance of allowing claimants access to court for adjudication of racial vilification claims. This enables claimants to exercise their autonomy, and to achieve appropriate vindication of the wrong done to them. However, adjudication has certain risks for claimants. This is particularly so at the federal level in Australia, where proceedings are determined by a court rather than a tribunal. ${ }^{206}$ As outlined in this section, the risks of litigation are particularly serious for claimants who are inexperienced and poorly resourced.

This section argues that cost rules, and particularly the rule that an unsuccessful applicant may be ordered to pay the respondent's legal costs, should be modified in respect of proceedings for racial vilification. This is because that rule can deter complainants from seeking to vindicate their rights in court. Therefore, given the public interest in allowing access to adjudication of racial vilification claims, costs should be ordered only in limited circumstances. This

203

204

205

206

Gelber and McNamara, 'Lessons from Australia' (n 5) 656.

Ibid 508 .

Ibid 511. It is beyond the scope of this article to examine in detail what role the AHRC would have if complainants were granted direct access to adjudication. However, briefly, the AHRC could serve a similar function to the Victorian Equal Opportunity and Equal Rights Commission, in providing information on discrimination law and optional dispute resolution services.

Until 1995, the AHRC (then called the Human Rights and Equal Opportunity Commission) conducted informal hearings to determine discrimination complaints. However, in Brandy v Human Rights and Equal Opportunity Commission (1995) 183 CLR 245, the High Court determined that the AHRC could not make legally binding determinations resolving a discrimination complaint. As an administrative body, the AHRC could not exercise judicial power. 
section will outline the current costs rules, explain why those rules are inappropriate in relation to racial vilification claims, and then present a more appropriate rule regarding costs in such proceedings.

\section{Complexity, Uncertainty and Costs}

As mentioned above, commencing proceedings in the Federal Court or the Federal Circuit Court is the second stage in seeking redress for breach of Australia's racial vilification laws. ${ }^{207}$ Significantly, proceedings are conducted in a court rather than a tribunal. ${ }^{208}$ Adjudication of a claim by a court, rather than a tribunal, raises a range of challenges and risks, particularly for claimants. In summary, these are the complexity of procedural rules and substantive law, the uncertainty of the court's ultimate determination, and costs.

Regarding complexity, pt IIA of the RDA is complex both in its substantive aspects and in its procedural requirements. For example, applicants must prove that the alleged conduct was done 'because of' the person's race, colour or ethnic origin. $^{209}$ Numerous judicial statements have been made in relation to this requirement. ${ }^{210}$ The reported decisions establish that this requires a causal relationship between the act and the person's race, colour or ethnic origin, and this involves consideration of the respondent's 'purpose', as well as the nature of the respondent's conduct. ${ }^{211}$ However, in some cases applicants have been unable to prove this, even though there was evidence of a racial motive. ${ }^{212}$

Another reason for uncertainty is that claimants must often depend on favourable judicial inferences regarding findings of fact. Success in racial vilification proceedings relies to a large extent on whose interpretation of particular words and conduct is accepted by a court. ${ }^{213}$ Further, this high level of uncertainty tends to favour the party with greater resources. ${ }^{214}$ Scholars emphasise that claimants are often poorly resourced and less experienced than

Proceedings can be commenced only when a complaint has been terminated by the AHRC: AHRCA s 46PO.

Under state and territory discrimination laws, proceedings are determined by a tribunal rather than a court. See Rees, Rice and Allen (n 77) 823-4.

RDA s $18 \mathrm{C}$ (1).

See Bolt (n 11) [308].

Bropho v Human Rights and Equal Opportunity Commission (2004) 204 ALR 761, [71] (French J).

See, eg, Creek v Cairns Post Pty Ltd [2001] 112 FCR 352; Hagan v Trustees of Toowoomba Sports Ground Trust [2000] FCA 1615.

Gelber and McNamara, 'Mapping the Gaps' (n 5) 493. For example, in Hagan $v$ Trustees of Toowoomba Sports Ground Trust [2000] FCA 1615, the Court determined that, when all the relevant circumstances were taken into account, the use of the word 'nigger' on a public sign did not breach S 18C.

Gelber and McNamara (n 4) 318. 
respondents. ${ }^{215}$ Further, scholars such as Galanter argue that inexperienced and poorly resourced claimants have little chance of success in litigation, when proceeding against more-experienced and better-resourced respondents. ${ }^{216}$

However, the most serious risk faced by claimants in commencing and pursuing proceedings is not that of losing, but rather the risk of being ordered to pay the respondent's legal costs. ${ }^{217}$ Both the Federal Court and Federal Circuit Court have the power to award costs in any proceeding. ${ }^{218}$ Although this power is discretionary, the 'usual rule' is that the unsuccessful party is ordered to pay the successful party's legal costs. ${ }^{219}$ Courts have on several occasions ordered unsuccessful applicants in racial vilification matters to pay costs. ${ }^{220}$ Further, courts have also ordered applicants to pay costs on an indemnity basis (rather than merely on a party/party basis) when an offer of settlement has been unreasonably refused. ${ }^{221}$

\section{Current Cost Rules Are Not Appropriate}

Courts have consistently rejected the argument that different costs rules apply to proceedings brought under the AHRC. ${ }^{222}$ However, courts have identified four factors that may militate against ordering an unsuccessful claimant to pay costs

Ibid. Parties are entitled to certain limited forms of assistance by the AHRC in relation to applications to court. Claimants are entitled to assistance in preparing the forms required to make such an application: AHRCA s 46PT. Applicants and respondents may apply to the AttorneyGeneral for assistance in respect of proceedings, and assistance may be provided if the AttorneyGeneral is satisfied that refusal would involve hardship, and that it is 'reasonable' to grant the assistance: AHRCA s 46PU.

Galanter (n 151). Therefore, scholars such as Gaze and Hunter emphasise the need for the state to provide free or subsidised legal representation for parties (usually applicants) who cannot afford such representation: Gaze and Hunter (n 82) 201-21. However, they also emphasise (at 222) that costs rules, rather than lack of legal representation, 'operate as a barrier to access for ... complainants'. This is because costs rules can deter even strong cases, and adverse costs awards are borne by a complainant personally: ibid 242 .

This article is not concerned with a claimant's chances of success in litigation per se. Rather, it is concerned with whether current costs rules are an inappropriate barrier, or deterrent, to claimants accessing adjudication.

Federal Court of Australia Act 1975 (Cth) s 43; Federal Circuit Court of Australia Act 1999 (Cth) s 79. Fetherston $v$ Peninsula Health [No 2] [2004] FCA 594 (Heerey J).

See, eg, Creek v Cairns Post Pty Ltd [2001] 112 FCR 352; Hagan v Trustees of Toowoomba Sports Ground Trust [2001] FCA 123. The unsuccessful applicant in the latter proceeding was ultimately declared bankrupt; see Trustees of the Toowoomba Sports Ground Trust v Hagan [2007] FMCA 910.

See, eg, Prior v Queensland University of Technology [No 3] [2016] FCCA 3399. In this proceeding, one respondent also sought an order for costs against the applicant's solicitor personally. The Court declined to make such an order, as the proceeding, although misconceived, was not 'hopeless or bound to fail' (at [15]-[19]).

222 See, eg, Fetherston $v$ Peninsula Health [No 2] [2004] FCA 594, [6]-[8] (Heerey J); Hagan $v$ Trustees of Toowoomba Sports Ground Trust [2001] FCA 123, [31]; Creek v Cairns Post Pty Ltd [2001] FCA 1150, [1] (Keifel J). 
in such proceedings. First, such proceedings are 'human rights' proceedings, ${ }^{223}$ in that they seek to vindicate a claimant's fundamental human rights. ${ }^{224}$ Second, anti-discrimination legislation has a 'beneficial' purpose. ${ }^{225}$ Third, such proceedings have a 'public interest' aspect, in that they benefit the public (by promoting important social purposes) and not merely the claimant individually. ${ }^{226}$ Similarly, Gelber and McNamara have emphasised that proceedings for racial vilification involve a strong public interest aspect. ${ }^{227}$ They argue that a person seeking to enforce such laws can be regarded as a 'private prosecutor' who 'act[s] on behalf of the group that has been targeted'. ${ }^{228}$

Finally, many discrimination complainants are members of disadvantaged and vulnerable racial and ethnic groups, and they consequently cannot afford legal representation. ${ }^{229}$ The AHRC's complaint statistics illustrate the very different profile of complainants, as compared to respondents. Whereas 94 per cent of complainants are individuals, most respondents are corporations, public authorities or government departments. ${ }^{230}$ Regarding complaints made under the $R D A, 61$ per cent of complainants were born outside Australia, and 21 per cent are Indigenous or Torres Strait Islander. ${ }^{231}$ In particular, Indigenous Australians face a range of challenges in accessing the legal system, such as language difficulties, low levels of legal knowledge, and entrenched socio-economic disadvantage. ${ }^{232}$

Therefore, many applicants must either self-represent or rely on pro bono legal assistance. ${ }^{233}$ Courts currently grant 'some latitude' to self-represented

Hagan v Trustees of Toowoomba Sports Ground Trust [2001] FCA 123, [31].

See also Varuhas (n 43), who argues (at 76 ) that torts such as defamation (which are actionable without proof of loss) can be regarded as a type of human rights protection, as they protect fundamental human interests. Racial vilification is relevantly similar to defamation, in that it concerns a person's public standing and dignity.

Fetherston v Peninsula Health [No 2] [2004] FCA 594, [9] (Heerey J). This is consistent with Fiss's argument that laws proscribing racial discrimination seek to promote important social purposes. See Fiss (n 148) 1089.

However, in Prior v Queensland University of Technology [No 3)][2016] FCCA 3399, the Court (at [5]) seemed to conflate the issue of whether the proceedings were by their nature in the 'public interest' on the one hand, with whether a particular proceeding had in fact had 'generated public interest' on the other.

Gelber and McNamara (n 4).

Ibid 316. However, Gelber and McNamara (at 331) note that complainants in racial vilification proceedings are often publicly labelled 'troublemakers', and that 'their motives [are] questioned and ridiculed'.

Astor and Chinkin (n 51) 364 .

AHRC (n 183) 5.

Ibid.

See, eg, Commonwealth Attorney-General's Department, A Strategic Framework for Access to Justice in the Federal Civil Justice System (Report, 2009) 153-5 ('Strategic Framework Report'). See also Commonwealth of Australia, Access to Justice Arrangements: Productivity Commission Inquiry Report (Report, September 2014) 6, 762-6 ('Access to Justice Report'). These issues are also experienced by members of other groups, such as those for whom English is not a first language.

AHRC (n 183) 25 ('Chart 6: Racial Discrimination Act - Outcomes of Finalised Complaints'). 
litigants regarding costs. ${ }^{234}$ However, the extent of this latitude is uncertain, particularly regarding whether an applicant is considered to have acted 'reasonably' in refusing an offer of settlement.

Although these factors may be relevant to costs determinations in particular proceedings, courts have emphasised that it is the role of Parliament, rather than the courts, to determine general rules regarding costs. In Fetherston $v$ Peninsula Health [No 2], 235 Heerey J stated that Parliament may provide that different costs rules apply in particular proceedings, but noted that it had not done so regarding proceedings under the AHRCA. ${ }^{236}$

The four factors outlined above apply to all proceedings commenced under the AHRCA, which includes discrimination proceedings. However, there are two additional reasons why Parliament should provide different costs rules regarding proceedings for racial vilification. First, a key feature of racial vilification as a legal wrong is its public occurrence and communicative nature. ${ }^{237}$ Therefore, according to corrective justice, claimants should be able to seek public vindication, through court proceedings, of the wrong committed against them. Second, applicants typically seek an order that vindicates their rights, rather than monetary compensation. This is consistent with the symbolic importance of redress for racial vilification as an inherently public and communicative wrong. ${ }^{238}$ Currently, however, a claimant may be ordered to pay the respondent's costs on an indemnity basis if they (the claimant) unreasonably refuses an offer of settlement. ${ }^{239}$ Cost rules may effectively deter claimants from seeking to vindicate their rights in court.

In Eatock $v$ Bolt, ${ }^{240}$ Bromberg J determined that the respondents (a newspaper and an employee writer) breached pt IIA by publishing two articles in the newspaper. The applicant sought, and the Court ordered, that the respondent newspaper publish a notice of the Court's determination in its newspaper and on its website. ${ }^{241}$ Although the claimant was successful, the respondent argued that it was entitled to indemnity costs, because the applicant had refused an offer of settlement on similar terms to the orders ultimately made by the Court. However, Bromberg J held that the successful applicant would not be deprived of her costs,

\footnotetext{
Refaat $v$ Barry [No 2] [2015] VSCA 268.

Fetherston $v$ Peninsula Health [No 2] [2004] FCA 594 (Heerey J).

Ibid [10].

See Part III(B)(2) above.

Ibid.

The fact that the applicant is self-represented is not in itself grounds for exempting them from a costs order; however, this may be relevant in considering whether an applicant has acted 'reasonably'. See Refaat $v$ Barry [No 2] [2015] VSCA 268.

(2011) 197 FCR 261.

Eatock v Bolt [No 2] (2011) FCA 1180 ('Bolt [No 2]').
} 
and would not be ordered to pay the respondent's costs, because she had not acted unreasonably in refusing that offer. ${ }^{242}$ In particular, Bromberg J referred to the evidential findings achieved by the applicant, which were part of the Court's published reasons. These findings included that the published articles were substantially false, and that the applicants genuinely identified as Aboriginal, rather than (as the articles suggested) choosing to identify as Aboriginal for financial and career benefits. ${ }^{243}$ Bromberg $J$ held that these public findings contributed to the vindication the applicant achieved. ${ }^{244}$

However, courts can just as easily decide against an applicant on the issue of reasonableness. In Prior $v$ Queensland University of Technology [No 3], 245 the Court held that the applicant had unreasonably refused an offer of settlement (in the form of an apology) by the respondent, and she was therefore ordered to pay costs on an indemnity basis. ${ }^{246}$ Therefore, costs orders present an extreme risk, particularly for complainants. Determining whether a complainant acted 'reasonably' in refusing a settlement offer depends on many factors, including a judge's assessment of the appropriateness of the redress sought.

In summary, the possibility of an adverse costs order, including indemnity costs, represents a significant risk for applicants in racial vilification (and discrimination) proceedings. Although courts have acknowledged that such proceedings are 'human rights' claims and that the legislation has a 'beneficial' character, they do not currently treat such proceedings differently regarding costs. $^{247}$ In addition, even successful applicants can be ordered to pay indemnity costs, if they are determined to have 'unreasonably' refused an offer of settlement.

Allowing disadvantaged members of society access to courts to vindicate their rights is a core obligation of the state in a liberal democracy. ${ }^{248}$ Members of

242 Ibid [42]. He also noted (at [47]) that the terms of settlement were inferior to the orders made.

243 Ibid. [42].

244 Ibid

245 [2016] FCCA 3399.

246 Ibid [24]. The Court emphasised in particular that the applicant had sought compensation and not merely a declaration. The Court stated (at [23]) that the relief sought by the applicant was therefore 'for the benefit of the applicant personally'. In Bolt [No 2] (n 241), Bromberg J (at [37]) emphasised that the applicant in that proceeding 'made no claim for money' and only sought a declaration. It is difficult to determine whether the Court in Prior was attempting to distinguish the decision in Bolt [No 2], and further whether the particular form of relief sought by an applicant is (or should be) relevant to the costs orders made by a court.

247 In some cases, unsuccessful applicants have been ordered to pay less than full costs. For example, in Creek v Cairns Post Pty Ltd [2001] FCA 1150, the unsuccessful applicant was ordered to pay onehalf of the respondent's costs, as the respondent unsuccessfully argued a defence under s 18D.

248 Strategic Framework Report (n 232) 1, 30. This Report highlights the significant practical barriers to accessing court experienced by Indigenous Australians and members of culturally and linguistically diverse communities. These barriers include language, cultural and financial 
minority groups should not be deterred from vindicating their rights by prohibitive rules concerning costs. Rather, the state should ensure that all members of society have access to courts to vindicate their rights. ${ }^{249}$

Therefore, Parliament should amend the AHRCA to provide that costs orders may be made against applicants in racial vilification proceedings only in certain limited circumstances. There are currently exemptions in various statutes that modify costs rules in similar circumstances. These provisions provide that costs orders may only be made if the court is satisfied that the proceeding was instituted vexatiously or without reasonable cause, or the applicant acted unreasonably and caused the respondent to incur costs. ${ }^{250}$ This rule is adequate to deter vexatious or unmeritorious claims, and to encourage timely settlement. ${ }^{251}$ Scholars such as Jean Sternlight highlight that the cost regime under the AHRCA is particularly harsh and punitive to complainants who fail. ${ }^{252}$

Although courts have declined to recognise such proceedings as an exception to the usual rule as to costs, Parliament should legislate to recognise the strong public interest in shielding complainants from costs orders in racial vilification proceedings, provided the proceedings were not instituted vexatiously or that the complainant has not unreasonably caused the respondent to incur costs.

\section{CONCLUSION}

This article has argued that redress for breach of Australia's racial vilification laws should be understood within a corrective justice framework. Breach of pt IIA of the RDA is a civil wrong, and claimants should be entitled to appropriate forms of legal redress. Corrective justice emphasises the right of claimants to vindication of their equal worth and standing as full members of society. As an inherently public and communicative wrong, racial vilification specifically requires public vindication of a wronged person's rights, including appropriate access to courts for an authoritative determination of those rights.

This article has argued for two amendments to the AHRCA, which would promote corrective justice for claimants. First, claimants should have direct access to adjudication, rather than having to attempt conciliation first. Second,

constraints: ibid 153-4. See also Australian Law Reform Commission, Cost Shifting - Who Pays for Litigation? (Report No 57, October 1995).

249 Access to Justice Report (n 232) 6, 464.

250 See, eg, Fair Work Act 2009 (Cth) s 570; Public Interest Disclosure Act 2013 (Cth) s 18.

251 See Freedom of Speech Report ( $(\mathrm{3})$, and subsequent amendments to the AHRCA, which emphasise the importance of costs orders in deterring trivial or vexatious complaints.

252 Jean R Sternlight, 'In Search of the Best Procedure for Enforcing Employment Discrimination Laws: A Comparative Analysis' (2004) 78(5) Tulane Law Review 1401. Sternlight highlights that courts hearing discrimination cases in the United States award costs only in exceptional circumstances, and in the United Kingdom discrimination proceedings are generally conducted in tribunals, rather than through the courts. 
costs rules should be modified so that claimants can be ordered to pay costs only if they commence proceedings vexatiously, or if they otherwise unreasonably caused the respondent to incur costs. These amendments would support claimants who seek vindication of their rights in court, which is necessary to provide appropriate redress for the wrong of racial vilification, and also to respect the autonomy of claimants.

Understanding redress for racial vilification within a corrective justice framework indicates that certain proposals advanced by scholars to make such laws 'more effective' would in fact not be appropriate. In particular, Gelber and McNamara propose that racial vilification laws be amended 'to allow any member of the community to initiate a complaint'. ${ }^{253}$ They argue that this would improve the effectiveness of the enforcement of these laws and remove the burden of enforcement from members of target communities. ${ }^{254}$ However, this proposal is not consistent with corrective justice, which requires a correlation between the wrongdoer and the person seeking redress. By definition, a person who has not been wronged (either individually or as a member of the target group) is not entitled to seek redress in respect of that wrong.

In addition, Gelber and McNamara propose that a governmental agency (such as an anti-discrimination commission) be given power to initiate a complaint in relation to incidents of racial vilification. ${ }^{255}$ Again, they argue that this would improve the effectiveness and efficiency of enforcement, and that it would remove the burden of enforcement from victims. ${ }^{256}$ Similar proposals have been made by scholars in relation to discrimination proceedings. ${ }^{257}$ However, enforcement of racial vilification laws by a governmental agency would not only break the required correlation between the wrongdoer and the person seeking redress, it would also potentially undermine the autonomy of victims. As mentioned above, pt IIA of the RDA conceives of racial vilification as a wrong against members of particular racial groups. Potentially, agency enforcement seriously undermines the autonomy, or choice, of members of target groups regarding whether, when and how to seek redress under racial vilification laws. Although agency enforcement may be more 'effective' in some sense, it does not prioritise victim autonomy in the way required by principles of corrective justice.

This article proposes a new framework for understanding the types of redress provided for breach of pt IIA of the RDA. This framework - corrective

\footnotetext{
253 Gelber and McNamara, 'Mapping the Gaps' (n 5) 509. This would essentially create a form of 'open standing'.

Ibid.

Ibid 510

Gelber and McNamara (n 4) 309-12. Further, they argue that racial vilification is a 'public wrong' and therefore that it is inappropriate to leave enforcement to individuals.

257 See, eg, Gaze and Hunter (n 82) 246-7; Dominique Allen, 'Strategic Enforcement of AntiDiscrimination Law: A New Role for Australia's Equality Commissions' (2011) 36(3) Monash University Law Review 103.
} 
justice - emphasises the rights and interests of claimants (or victims of racial vilification), as these rights and interests have either been ignored in the current debate concerning Australia's racial vilification laws, or have not been understood as part of an overarching conceptual framework. Providing appropriate redress under racial vilification laws obviously involves balancing competing values, such as the rights and interests of both complainants and respondents. Also, principles (such as corrective justice) must be balanced with notions of efficiency and effectiveness. This article has presented corrective justice as an appropriate framework for conceptualising redress under racial vilification laws. However, important work remains to be done to implement this framework in practical terms. 
